\title{
THE INFLUENCE OF SHEAR SPAN RATIO ON LOAD CAPACITY OF FIBRE REINFORCED CONCRETE ELEMENTS WITH VARIOUS STEEL FIBRE VOLUMES
}

\author{
Remigijus Šalna, Gediminas Marčiukaitis \\ Dept of Reinforced Concrete and Masonry Structures, Vilnius Gediminas Technical University, \\ Saulètekio al.11,LT-10223 Vilnius, Lithuania.E-mail:gelz@st.vtu.lt \\ Received 23 June 2006; accepted 16 March 2007
}

\begin{abstract}
This paper analyses the influence of steel fibre volume and shear span ratio on the strength of fibre reinforced concrete elements in various states of stress. 36 beams with three different shear spans $(a / h=1,1,5$, and $2 \%)$ and three different fibre volumes $(1,1,5$, and $2 \%$ ) were tested to examine how these factors influence the behaviour of such elements. Test results suggest that steel fibre volume and shear span can increase load capacity, plasticity and cracking. Experimental research showed that steel fibre volume has different influence at different shear span ratios. Regression analysis of experimental data was carried out and empirical approach showing different effect of these factors was proposed. Furthermore, test results were compared with different theoretical and empirical approaches of other authors.
\end{abstract}

Keywords: steel fibre reinforced concrete, load capacity, plasticity.

\section{Introduction}

Different building structures, such as beamless reinforced concrete slabs, footings of foundation, shear in beams, have a brittle failure mode and versatile complex stress behaviour [1-3]. This failure occurs when tensile strength exceeds limit values. This failure is usually very sudden due to brittle behaviour of plain concrete in tension. Steel fibre reinforced concrete (SFRC) is wellknown as a plastic composite material with significantly higher tensile strength, resistance to crack formation and propagation, which can replace brittle failure mode to plastic in punching shear [4-6], or shear in beams [7-12].

The research of stress-strain state shows that failure is influenced by bending moment and shear force ratio (shear span and depth ratio) [13, 14], because shear stresses have significant effect on principal stresses. Design methods of tensile strength of SFRC and its behaviour in various states of stress are differently estimated by some authors $[4,7,15,16]$. It shows that stress and strain state of fibre reinforced concrete at different bending moment and shear span ratios is not fully analysed. That's why it is reasonable to analyse SFRC as a composite material in versatile complex stress behaviour.

This paper presents results of the test in flexural steel fibre reinforced concrete beams under different bending moment and shear force (shear span and depth) ratios.

Regression analysis of experimental data was carried out, and empirical approach showing different effect of these factors was proposed. Furthermore, test results were compared with different theoretical and an empirical approaches of other authors $[4,7,15,16]$.

\section{Analysis of SFRC tensile strength estimation methods}

The main factors influencing SFRC tensile strength are these: volume and distribution of steel fibres in principal section, anchorage of fibre in concrete matrix, yield strength of fibre and strength of concrete $[17,18]$. Distribution of steel fibres in principal section and anchorage of fibre in concrete matrix is viewed differently by various authors [4, 7, 15, 16]. For example, method [15], based on modelling SFRC structure, estimates these factors by separate coefficients, replacing dispersed reinforcement by equivalent reinforcement. Whereas in method [16], the distribution of steel fibres in principal section is based on stochastic theory. In this method, failure occurs when concrete exceeds shear strength between fibres. In methods $[4,7]$, all these factors are estimated by empirical coefficients.

According to method [15], SFRC tensile strength before cracking is shown in $\mathrm{Eq}(1)$ :

$$
f_{S F R C, t}=f_{c t}\left(1-V_{f}\right)+\sigma_{f} V_{f} \lambda_{p} \lambda_{\text {or }} \leq f_{y} V_{f} \lambda_{\text {red }} \text {. }
$$
element:

Eq (2) represents tensile strength of SFRC cracked

$$
f_{S F R C, t}=\lambda_{\text {red }} f_{y} V_{f}=0,41\left(1-\frac{\beta f_{y} D_{f}}{4 f_{c}^{\prime} L_{f}}\right) f_{y} V_{f} .
$$

SFRC compression strength is expressed in Eq (3):

$$
f_{S F R C, c}=f_{c}^{\prime}+\lambda_{r e d} V_{f} f_{y},
$$


where $f_{c t}$ is tensile strength of concrete, $V_{f}$ - volume fraction of steel fibres, $\sigma_{f}$ - stresses in fibres, $f_{y}-$ yield strength of fibres, $D_{f}$ - fibre diameter, $L_{f}$ - fibre length, $\beta=f_{c}^{\prime} / \tau_{u}$ - coefficient, $f_{c}^{\prime}=0,7 f_{c, \text { cube }}-$ compression characteristic strength of concrete, $\tau_{u}$ - fibre anchorage stresses in concrete matrix, obtained from test results, $\lambda_{\text {red }}-$ coefficient replacing chaotic reinforcement by equivalent reinforcement. It is calculated in $\mathrm{Eq}(4)$ :

$$
\lambda_{\text {red }}=\lambda_{p} \lambda_{\text {or }} \lambda_{\text {an }}
$$

where $\lambda_{p}$ is coefficient, evaluating the distribution of fibres in normal section, $\lambda_{o r}$ - fibre orientation coefficient, $\lambda_{\text {an }}-$ fibre anchorage coefficient.

Eq (5) represents SFRC tensile strength according to method [16]:

$$
f_{S F R C, t}=0,375 f_{c t} \frac{L_{f}}{D_{f}} \sqrt{V_{f}} K_{o},
$$

where $K_{o}$ - fibre orientation coefficient, calculated in $\mathrm{Eq}(6,7)$ :

$$
\begin{gathered}
\text { if } t \leq L_{f}, K_{o}=0,5+0,097 \frac{L_{f}}{t} ; \\
\text { if } t>L_{f}, K_{o}=0,637+0,296 \frac{L_{f}}{t},
\end{gathered}
$$

where $t$ - width of cross-section.

In method [4], SFRC tensile strength is expressed by $\mathrm{Eq}(8)$ :

$$
f_{S F R C, t}=\left(0,54+0,09 V_{f}\right) \sqrt{0,8 f_{c}},
$$

where $f_{c}$-concrete cylinder compressive strength.

Eq (9) presents SFRC tensile strength according to method [7]:

$$
f_{S F R C, t}=\frac{f_{\text {cuf }}}{20-\sqrt{F}}+0,7+\sqrt{F},
$$

where $f_{\text {cuf }}$ - cube strength of SFRC concrete (MPa), and $F$ - fibre factor, calculated in Eq (10):

$$
F=\frac{L_{f}}{D_{f}} V_{f} d_{f}
$$

where $d_{f}$ - bond factor: 0,5 for round fibres, 0,75 for crimped fibres, and 1,00 for indented ones.

The analysis of these methods clearly illustrates that the distribution of steel fibres in principal section, and the anchorage of fibre in concrete matrix are estimated differently. Also, different concrete strength characteristics in the discussed methods were used. Furthermore, nearly all methods analysed $[4,7,16]$ are based on empirical findings of the authors. Eq (1), provided by method [15], is more accurate, as it is based on modelling SFRC structure.

\section{Methodology of experimental research}

Three series of tests with three different shear spans $(a / h=1,1,5$, and 2, Fig 1$)$ and three different fibre volumes $(1,1,5$, and $2 \%)$ were carried out in this experimental program. The research is aimed to imitate various stress strain states with different fibre volumes ranging from simple bending elements $[19,20]$ to deep beams [14]. Therefore, such different shear span values were chosen. 36 specimens, including plain concrete, were tested. The cross-section of specimens $b \times h=100 \times 200 \mathrm{~mm}$, and length $l=500 ; 750 ; 1000 \mathrm{~mm}$. Fig 2 shows test setup. Water cement ratio $\mathrm{w} / \mathrm{c}$ for all beams was 0,51 .

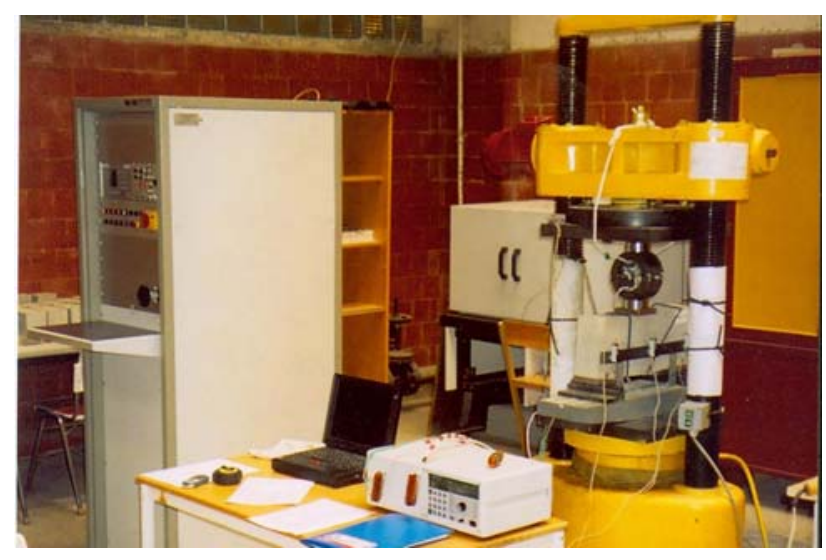

Fig 1. Test setup

In the tests reported, fibre type MPZ50/1, Art. No 1010 (Metalproducts Ltd) was applied, where fibre length was $50 \mathrm{~mm}$ and its diameter $1 \mathrm{~mm}$. These dimensions correspond to the aspect ratio of $l / d=50 / 1=50$. Nominal yield strength of steel fibres was $f_{y k}=1100 \mathrm{MPa}$. Specimens were reinforced with three volume fractions: $1, \quad 1,5$ and $2 \%\left(78,5 \mathrm{~kg} / \mathrm{m}^{3}\right.$, $117,8 \mathrm{~kg} / \mathrm{m}^{3}$, and $157 \mathrm{~kg} / \mathrm{m}^{3}$, respectively).

During the test, midspan deflections, tensile and compression strain, as well as strain in the tension zone near the crack of the beams, were measured. The load was applied to the beams through a $100 \times 100 \times 10 \mathrm{~mm}$ steel plate. Fig 1 shows a loading configuration and layout of different gauges.

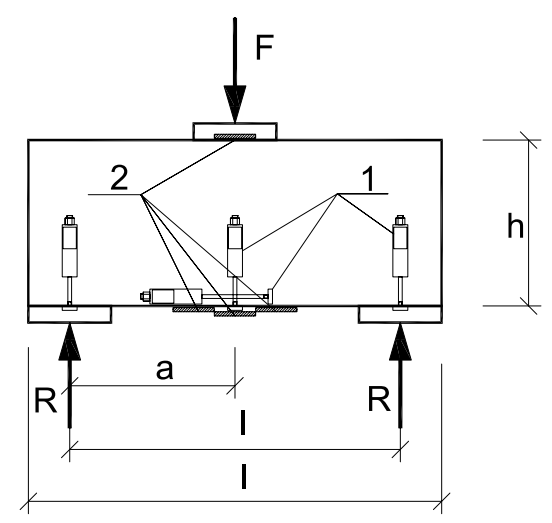

Fig 2. Loading configuration and location of gauges, where 1 is deflection gauges, and 2 is strain gauges 
Average load capacities of tested beams are presented in Table 1, and their graphical expression in Fig 3. Typical failure of specimens is demonstrated in Fig 4.

Table 1. Summary of test programme

\begin{tabular}{c|c|c|c|c}
\hline \multirow{2}{*}{$V_{f}, \%$} & \multirow{2}{*}{$\begin{array}{c}f_{c, \text { cube }}, \\
\mathrm{MPa}\end{array}$} & \multicolumn{3}{|c}{$\begin{array}{c}\text { Average load capacities of beams } \\
F_{u}, \mathrm{kN}\left(\beta=F_{u, S F R C} / F_{u, \text { Concrete }}\right)\end{array}$} \\
\cline { 3 - 5 } & & $a / h=1$ & $a / h=1,5$ & $a / h=2$ \\
\hline $0 \%$ & 46,30 & $41,50(1,00)$ & $26,4(1,00)$ & $19,13(1,00)$ \\
\hline $1 \%$ & 45,29 & $67,14(1,62)$ & $33,30(1,26)$ & $21,9(1,14)$ \\
\hline $1,5 \%$ & 45,20 & $74,23(1,79)$ & $39,40(1,49)$ & $27,90(1,46)$ \\
\hline $2 \%$ & 42,95 & $77,10(1,86)$ & $41,20(1,56)$ & $29,46(1,54)$ \\
\hline
\end{tabular}

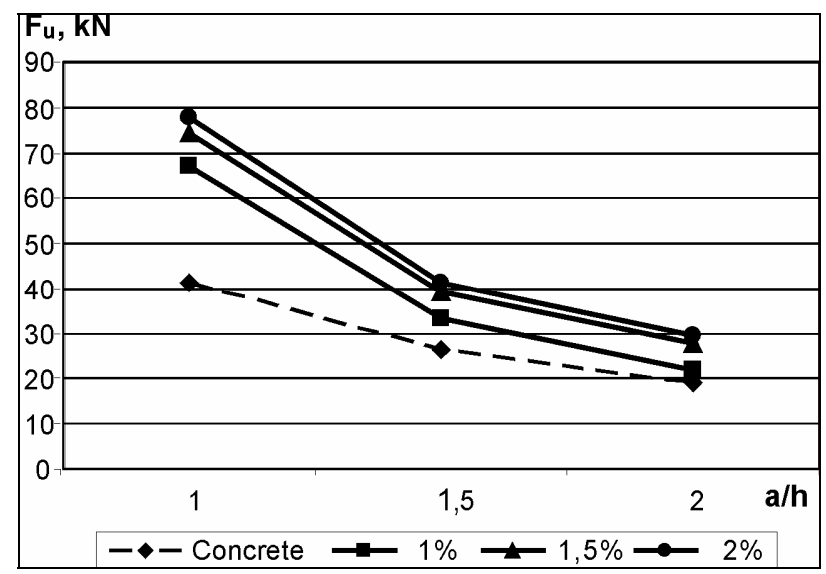

Fig 3. Influence of fibre volume $V_{f}$ and shear span ratio $a / h$ on load capacity of the tested beams

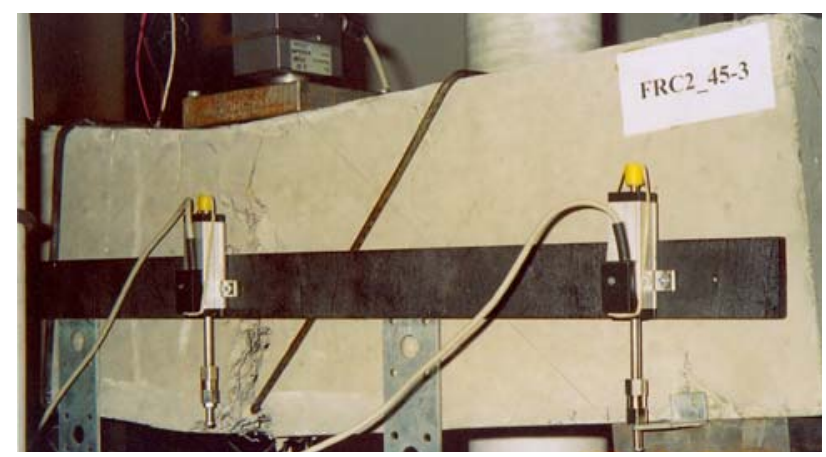

Fig 4. Failure of specimens $(a / h=1,5)$

As the curves on Fig 3 show, the greatest influence on load capacity is observed at shear span ratio $a / h=1$. This case reminds of the case of deep beam in the way that principal stresses are strongly influenced by shear stresses. After increasing fibre volume from 1 to $2 \%$, when $a / h=1$, load capacity grows from 1,62 to 1,89 times. At higher values of shear span ratio, the increase of load capacity is not so significant. For example, when $a / h=1,5$ and $a / h=2$, the increase from 1,26 to 1,56 and 1,14 to 1,54 times, respectively, is observed.
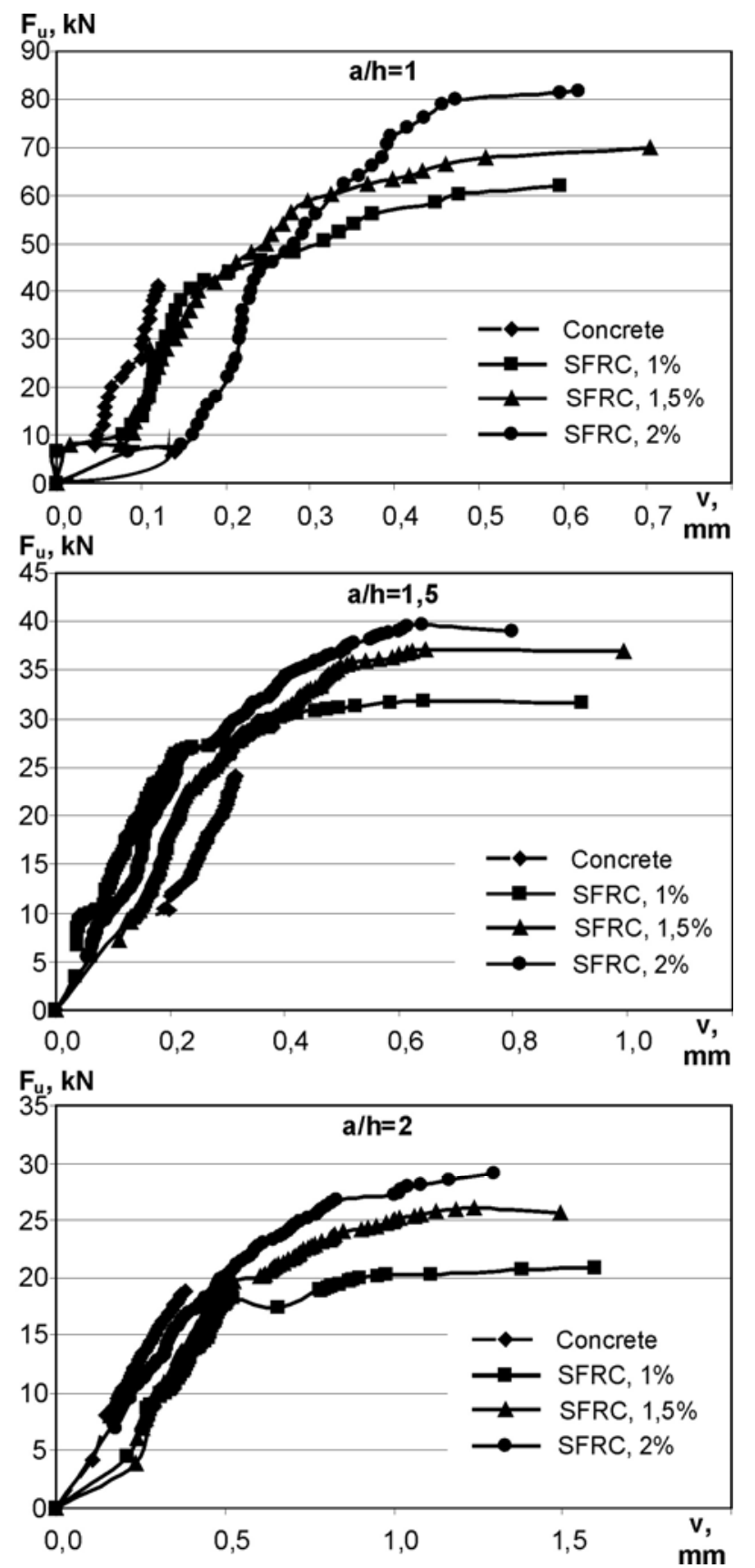

Fig 5. Load deflection curves with various fibre volumes $V_{f}$ and shear span ratios $a / h$

Fibre volume $V_{f}$ and shear span ratio $a / h$ have significant influence on deflection, plasticity and cracking of the element. Besides, this influence is different, depending on these factors. As the curves presented on Fig 5 show, with different $V_{f}$ and $a / h$, three different groups of elements can be defined in respect of load capacity as well as deflections. At high values of ratio $a / h$, deflections significantly grow with a small rise in load capacity, whereas at low values of ratio $a / h$, the growth of both deflections and load capacity is observed. It is clearly seen that load capacity, in variation of $V_{f}$ at different $a / h$, is influenced by $V_{f}$. 

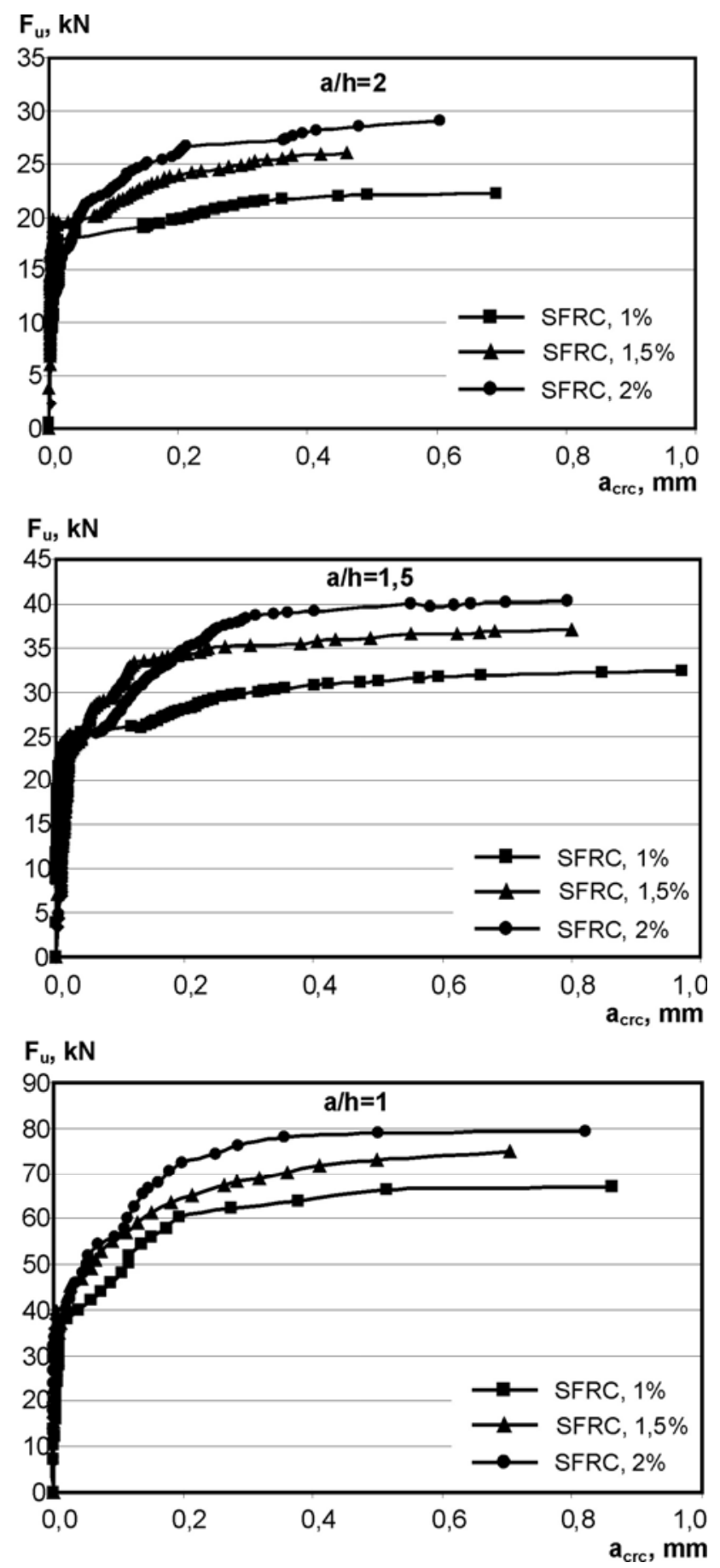

Fig 6. Cracking of elements with various fibre volumes $V_{f}$ and shear span ratios $a / h$

These factors also influence the cracking of elements (Fig 6). When $a / h=1,1,5$ and 2, cracks appear at failure loads $(0,6 \ldots 0,7),(0,7 \ldots 0,8)$ and $(0,8 \ldots 0,85) F_{u}$, respectively.

The analysis of tension and compression strains showed (Fig 7) that with increasing $a / h$, plastic strains can be observed at higher load capacity values: when $a / h=1,1,5$ and 2 , ductile strain appears at failure loads $(0,4 \ldots 0,55),(0,55 \ldots 0,65)$ and $(0,65 \ldots 0,78) F_{u}$, respectively.
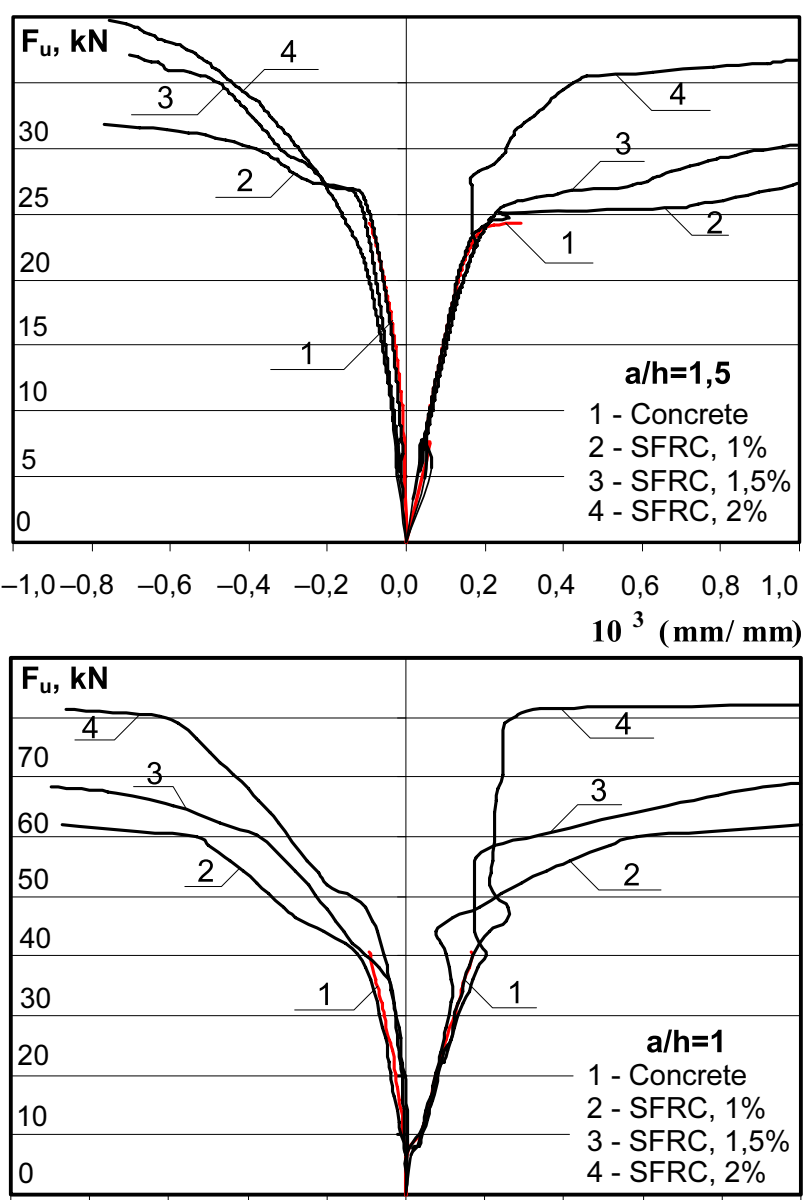

$\begin{array}{llllllllll}-1,0-0,8 & -0,6 & -0,4 & -0,2 & 0,0 & 0,2 & 0,4 & 0,6 & 0,8 & 1,0\end{array}$

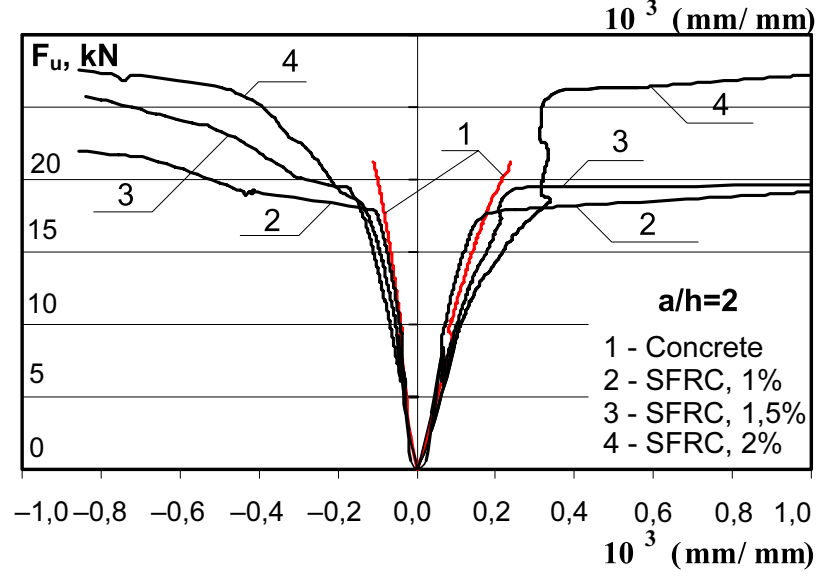

Fig 7. Tension and compression strains with various fibre volumes $V_{f}$ and shear span ratios $a / h$

Fibre volume has a significant influence on plasticity and compression zone of the element. With small $V_{f}$, normal crack destroys compression zone in nearly the same manner as in the concrete element. With the increase of $V_{f}$, compression zone plastic hinge is formed like one in simple bending beam. Besides, fibre volume has significant influence on the height of compression zone. Experiments show that the average height of compression zone at $0,5 F_{u}$, was equal to $64-65 \mathrm{~mm}$ in con- 
ventional concrete element. In SFRC beams it was noticeably greater: the average height of compression zone, at fibre volume $V_{f}=1,1,5$ and $2 \%$, was equal to 68-72, 72-75 and 76-78 $\mathrm{mm}$, respectively.

In conclusion, the influence of shear stresses on principal stresses and fibre volume effect on the height of compression zone are the main factors determining load capacity.

\section{Comparison and analysis of theoretical and ex- perimental results}

The comparison of theoretical and experimental results, with the variation of $V_{f}$, at different $a / h$, is presented in Figs 8, 9.

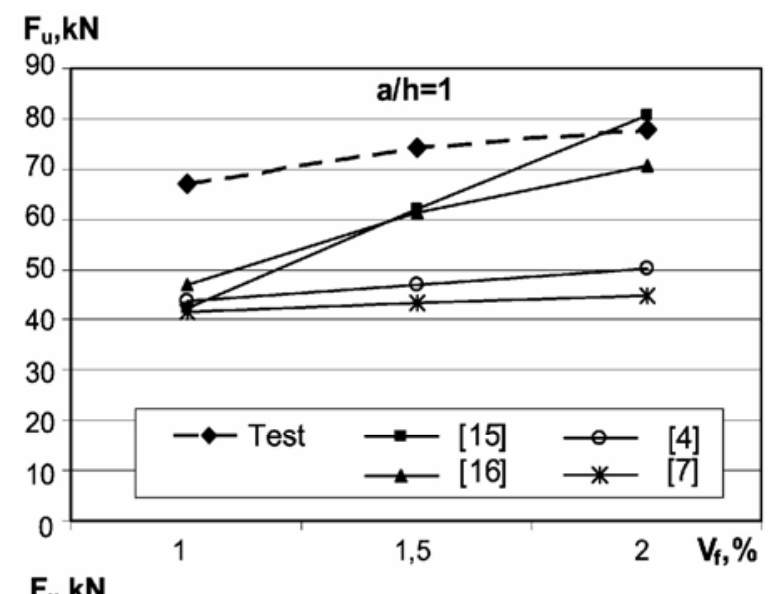

\section{$\mathrm{F}_{\mathrm{u}}, \mathrm{kN}$}
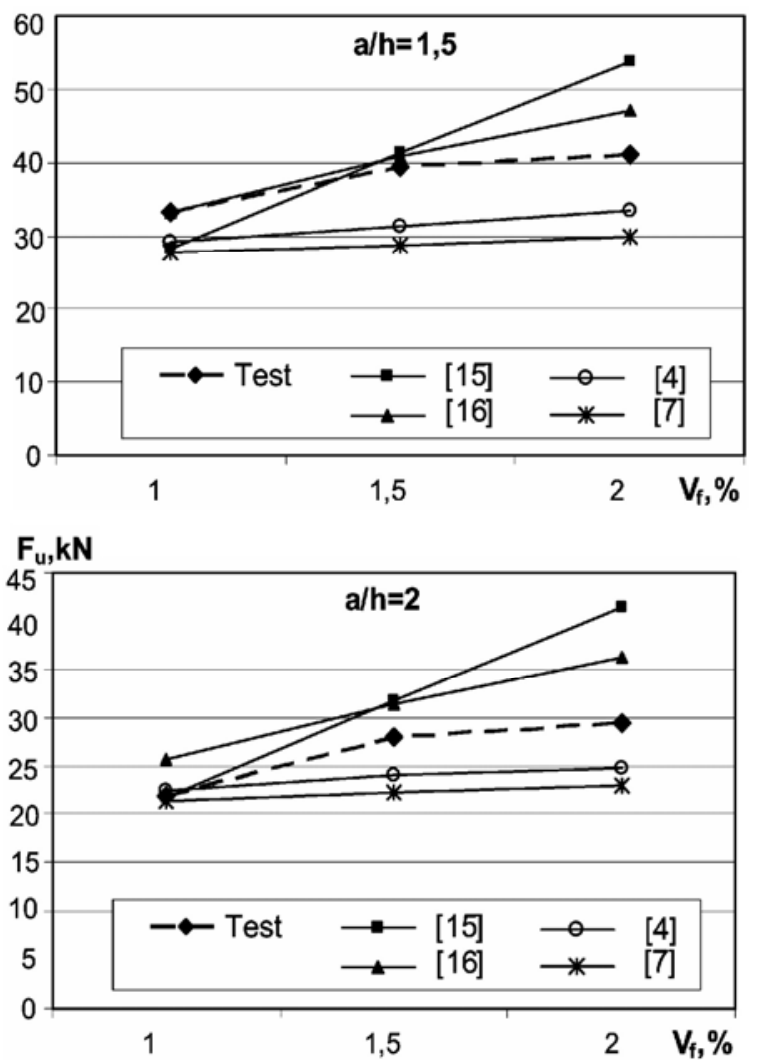

Fig 8. Influence of fibre volume on load capacity at various $a / h$
Comparing theoretical methods, all authors estimate fibre volume as a linear function. The character of curves is similar in empirical methods [4, 7] (curves are parallel). The character of curves in methods $[15,16]$, compared with methods [4, 7], is not similar (they are not parallel), because fibre volume was evaluated using SFRC structure modelling and not empirical coefficients. However, though having different characters, the curves in methods $[15,16]$ better correspond to test results.
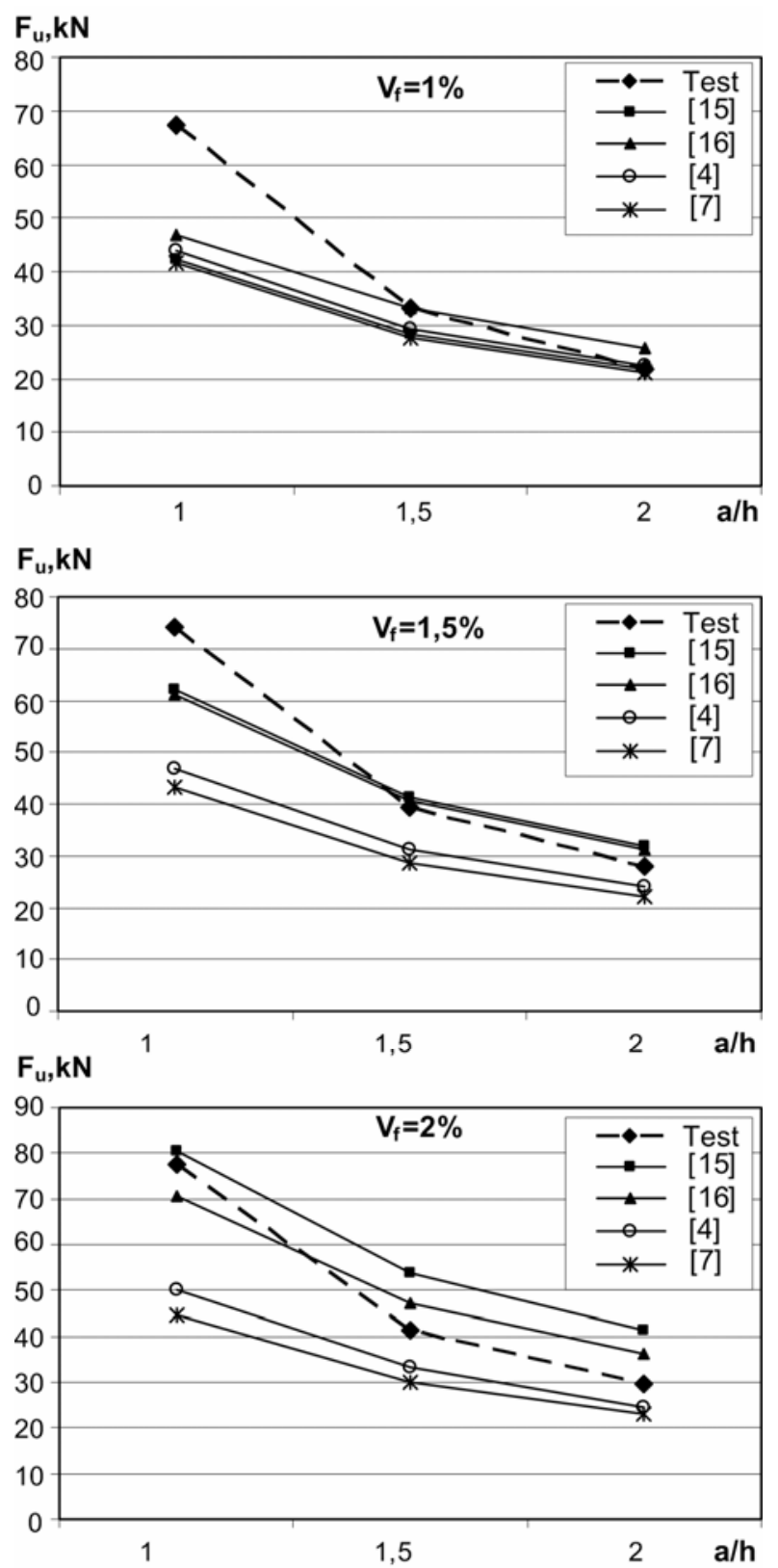

Fig 9. Influence of shear span ratio on load capacity at various fibre volume $V_{f}$

Comparing theoretical and test results, method [15] most closely corresponds to test results. However, the influence of $V_{f}$ is overestimated in some cases and even exceeds test results. Methods [4, 7, 16] are more conservative. 
Table 2 presents how differently authors estimate the influence of fibre volume on load capacity. The table also shows empirical expressions provided by regression analysis of test results. The ratio of SFRC and concrete specimens load capacities is expressed by equations.

Table 2. The ratio of SFRC and concrete specimens load capacities in variation of $V_{f}$

\begin{tabular}{l|l|l}
\hline \multicolumn{1}{c|}{ Method } & $y=F_{u, S F R C} / F_{u, \text { Concrete }}$ & $\begin{array}{c}\text { Reliability of } \\
\text { function (variation } \\
\text { factor) }\end{array}$ \\
\hline$[15]$ & $y=0,913+0,202 V_{f}$ & $0,613(0,168)$ \\
& $\left(y=0,913+0,06 V_{f}^{3}\right)$ & $0,953(0,058)$ \\
\hline$[16]$ & $y=0,972+0,505 V_{f}$ & $0,991(0,049)$ \\
\hline$[4]$ & $y=1,000+0,165 V_{f}$ & $0,999(0,001)$ \\
\hline$[7]$ & $y=1,021+0,167 V_{f}$ & $0,953(0,039)$ \\
\hline Regression & & \\
analysis & $y=1,021+0,585 V_{f}$ & $0,955(0,098)$ \\
$a / h=1$ & $y=0,993+0,302 V_{f}$ & $0,928(0,067)$ \\
$a / h=1,5$ & $y=0,996+0,292 V_{f}$ & $0,906(0,075)$ \\
$a / h=2$ &
\end{tabular}

Equations in Table 2 show that the influence of $V_{f}$ can be expressed by linear function (reliability is high and variation factor is low). Linear function is applied in methods $[4,7,16]$, but it could not be applied to method [15] (Eqs 1, 2), because such values can exist, at which $f_{S F R C, t}<f_{c, t}$. Empirical expressions, provided by regression analysis, clearly show different influence of $V_{f}$ on load capacity at different $a / h$.

This effect can be explained by decreasing ratio $a / h$, in deep beams influenced not only by bending, but bending with shear. Besides, compared with plain concrete, SFRC behaves differently in shear, therefore such great difference occurs. This influence, the so-called "arch action", is expressed through empirical coefficients by many authors $[8,9,13]$, analysing reinforced concrete behaviour in shear. However, this effect for SFRC is estimated by the same equations. The difference between plain concrete and SFRC is clearly illustrated in Fig 3.

$V_{f}$, and $a / h$ can be expressed as one function

(Fig 10). This function cannot be expressed as a linear one, because reliability is only 0,83 and variation factor exceeds 0,14 . After regression analyses of 36 beams, the influence of these factors can be demonstrated by the following polynomial function:

$$
\beta=\frac{F_{u, \text { SFRC }}}{F_{u, \text { Concrete }}}=\left(\begin{array}{l}
a^{\prime}+b \frac{a}{h}+c V_{f}+d^{\prime}\left(\frac{a}{h}\right)^{2}+e V_{f}^{2}+ \\
f\left(\frac{a}{h}\right) V_{f}+g\left(\frac{a}{h}\right)^{3}+h V_{f}^{3}+ \\
i\left(\frac{a}{h}\right) V_{f}^{2}++j\left(\frac{a}{h}\right)^{2} V_{f}
\end{array}\right)
$$

where $a^{\prime}=3,403, b=-5,218, c=1,937, d^{\prime}=3,634$, $e=0,498, f=-2,331, \quad g=-0,816, \quad h=-0,248$, $i=0,195$, and $j=0,560$.

Reliability of polynomial function is 0,966 , and variation factor is 0,067 .

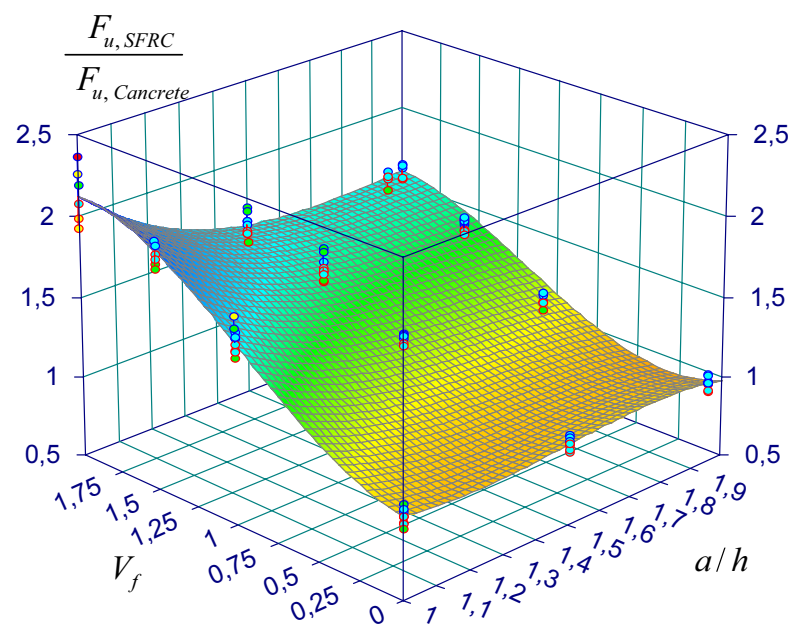

Fig 10. Graphical representation of function

However, quite good results can be achieved with a more simple function. The increase of load capacity within the range of $a / h=1 . . .2$ and $V_{f}=1 . .2 \%$, can also be expressed in the following way:

$\beta=\frac{F_{u, S F R C}}{F_{u, \text { Concrete }}}=\left(1,158-\frac{0,249}{(a / h)^{2}}-0,312 V_{f}^{0,5}\right)^{-1}$.

In this equation, the influence of shear span ratio and fibre volume on load capacity can be estimated with reliability of the function equal to 0,92 and variation factor equal to 0,097 .

\section{Conclusions}

1. Test results show that plasticity, cracks propagations and load capacity of elements are greatly influenced by steel fibre volume and shear span.

2. Load capacity of tested beams, in variation of volume fraction at different $\mathrm{a} / \mathrm{h}$, is different. When $a / h=1$, load capacity grows from 1,62 to 1,89 times. At higher values of shear span ratio, the increase of load capacity is not so significant. For example, when $a / h=1,5$ and $a / h=2$, the increase from 1,26 to 1,56 and 1,14 to 1,54 times, respectively, is observed.

3. The analysis of theoretical methods demonstrates that fibre volume, distribution of steel fibres in principal section, anchorage of fibres in concrete matrix and concrete strength characteristics are estimated differently. These factors determine the difference between theoretical results.

4. Experimental researches show that fibre volume and shear span ratio is very important. This expression $\beta$ and those two mentioned above parameters can be ex- 
pressed as a surface function. Based on regression analysis of experimental data, empirical equation, evaluating these factors, was proposed.

\section{References}

1. VAINIŪNAS, P.; POPOVAS, V.; JARMOLAJEV, A. Punching Shear Behaviour Analysis of RC Flat Floor Slab to Column Connection. Journal of Civil Engineering and Management, 2002, 8(2), p. 77-82.

2. ŠALNA, R.; MARČIUKAITIS, G.; VAINIŪNAS, P. Estimation of Factors Influencing Punching Shear Strength of RC Floor Slabs. Journal of Civil Engineering and Management, 2004, 10(2), p. 137-142.

3. ŠALNA, R.; MARČIUKAITIS, G.; VAINIŪNAS, P. Analysis of Resistance to Punching Shear of Beamless Reinforced Concrete Floor Slabs. In Proc of the $8^{\text {th }}$ International Conference "Modern Building Materials, Structures and Technique", Vilnius, 19-22 May 2004. Selected papers, ed E. K. Zavadskas, P. Vainiūnas and F. M. Mazzolani, Vilnius: Technika, 2004, p. 615-619.

4. HARAJLI, M. H.; MAALOUF, D.; KHATIB, H. Effect of Fibres on the Punching Shear Strength of Slab Column Connections. Cement and Concrete Composites, 1995, 17(2), p. 161-170.

5. KUTZING, L.; KONING, G. Punching Behaviour of High Performance Concrete Columns with Fiber Cocktails. Lacer 5, University of Leipzig, 2000, p. 253-260.

6. CHEN, S. Strength of Steel Fiber Reinforced Concrete Ground Slabs. Structures and Buildings, 2004, 157(2), p 157-163.

7. NARAYANAN, R.; DARWISH, I. Y. S. Use of Steel Fibres as Shear Reinforcement. ACI Structural Journal, 1987, 84(3), p. 216-227.

8. ASHOUR, S. A.; HASSANAIN, G. S.; WAFA, F. F. Shear Behaviour of High-Strength Fiber Reinforced Concrete beams. ACI Structural Journal, 1992, 89(2), p. 176-184.

9. SHARMA, A. K. Shear Strength of Steel Fibers Reinforced Beams. ACI Journal, 1986, 84(4), p. 624-628.
10. LI, V. C.; WARD, R.; HAMZA, A. M. Steel and Synthetic Fibres as Shear Reinforcement. ACI Material Journal, 1992, 89(5), p. 499-508.

11. LI, V. C. On the Shear Behaviour of Engineered Cementitious Composites. Advanced Cement Based Materials, 1993, 1(3), p. 142-149.

12. KWAK, Y. K.; KIM, W. S.; KIM, J. Shear Strength of Steel Fibers - Reinforced Concrete Beams without Stirrups. ACI Structural Journal, 2002, 99(4), p. 530-538.

13. ZSUTTY, T. Shear Strength Prediction of Separate Categories of Simple Beams Test. ACI Journal, 1971, 68(2), p. 138-143.

14. CHO, S. H. Shear Strength Prediction by Modified Plasticity Theory for Short Beams. ACI Structural Journal, 2003, 100(1), p. 105-112.

15. RABINOVICH, F. N. Composite Material Based on the Fibre Reinforced Concrete. The Questions of Theory, Design, Technology, Structures: monograph. Moscow: Publishing Office ASV, 2004. 506 p. (in Russian).

16. STEPANOVA, G. G. Researches of Steel Fibre Reinforced Concrete in Gradient of Stress State. Summary of Doctoral Thesis. St.-Petersburg Institute of Civil Engineering, St.-Petersburg, 1975. 28 p. (in Russian).

17. MARČIUKAITIS, G. The Principles of Creation and Prognoses of Structures Composites. Vilnius, Technika, 1998. 134 p. (in Lithuanian).

18. SWAMY, R. N.; MAGNAT, P. S.; RAO, C. V. S. K. The Mechanics of Fiber Reinforcement of Cement Matrices. In Fibre reinforced concrete, Special Publication No 44, American Concrete Institute, Farmington Hills, Michigan, 1974, p. 1-28.

19. MAALEJ, M.; LI, V. C. Flexural Strength of Fiber Cementitious Composites. ASCE Journal of Materials in Civil Engineering, 1994, 6(3), p. 390-406.

20. MAALEJ, M.; LI, V. C. Flexural/Tensile Strength Ratio in Engineering Cementitious Composites. ASCE Journal of Materials in Civil Engineering, 1994, 6(4), p. 513-527.

\title{
JĖGOS PETIES IR AUKŠČIO SANTYKIO ITAKA BETONINIŲ ELEMENTŲ LAIKOMAJAI GALIAI, ESANT IVAIRIEMS DISPERSINIO ARMAVIMO KIEKIAMS
}

\author{
R. Šalna, G. Marčiukaitis
}

Santrauka

Straipsnyje analizuojama plieninių fibrų kiekio įtaka dispersiškai armuotam betonui, esant ịvairiems įtempimų būviams. 36 sijos su trimis skirtingomis lenkimo momento ir skersinés jëgos santykio reikšmėmis (arba a/h =1, 1,5, 2 santykiais) bei su trimis plieninių fibrų armavimo procentais $(1 \%, 1,5 \%, 2 \%)$ buvo išbandytos, siekiant nustatyti, kaip šie veiksniai daro itaką dispersiškai armuoto betono elgsenai. Eksperimentiniai tyrimai parodè, kad šie veiksniai turi didelę ịtaką dispersiškai armuotų betoninių bandiniu ilinkiams, pleišètumui, plastiškumui bei laikomajai galiai, be to, plieninių fibrų kiekis esant skirtingoms jëgos peties ir aukščio santykio reikšmėms, turi skirtingą ịtaką. Atlikus eksperimentinių tyrimų regresinę analizę, straipsnyje pateikta išraiška, parodanti skirtingą šių veiksnių ịtaką. Gauti eksperimentiniai rezultatai taip pat palyginti su įvairių autorių teoriniais skaičiavimo metodais.

Reikšminiai žodžiai: dispersiškai armuotas betonas, laikomoji galia, plastiškumas, pleišětumas.

Remigijus ŠALNA. PhD student, Dept of Reinforced Concrete and Masonry Structures. Vilnius Gediminas Technical University (VGTU), BSc (2000) and MSc (2002) in Civil Engineering at Vilnius Gediminas Technical University. Author of 5 scientific articles. Research interests: punching shear of plain and fibre reinforced conctete.

Gediminas MARČIUKAITIS. Professor, Doctor Habil, Dept of Reinforced Concrete and Masonry Structures. Vilnius Gediminas Technical University (VGTU). PhD (Kaunas Politechnical Institute, 1963). Research visit to the University of Illinois (1969). Doctor Habil (1980) at Moscow Civil Engineering University, Professor (1982). Author and co-author of 5 monographs, 6 text-books and more than 300 scientific articles. Research interests: mechanics of reinforced concrete, masonry and layered structures, new composite materials, investigation and renovation of buildings. 